\title{
Les clercs, les fidèles et les saints en Bourgogne médiévale
}

Textes réunis par Vincent Tabbagh

\section{(2) OpenEdition \\ Journals}

Édition électronique

URL : https://journals.openedition.org/cem/819

DOI : $10.4000 /$ cem.819

ISSN : 1954-3093

\section{Éditeur}

Centre d'études médiévales Saint-Germain d'Auxerre

Édition imprimée

Date de publication : 15 août 2005

ISSN : 1623-5770

\section{Référence électronique}

"Les clercs, les fidèles et les saints en Bourgogne médiévale », Bulletin du centre d'études médiévales d'Auxerre | BUCEMA [En ligne], 9 | 2005, mis en ligne le 08 novembre 2006, consulté le 22 septembre 2022. URL : http://journals.openedition.org/cem/819 ; DOI : https://doi.org/10.4000/cem.819

Ce document a été généré automatiquement le 22 septembre 2022.

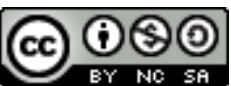

Creative Commons - Attribution - Pas d'Utilisation Commerciale - Partage dans les Mêmes Conditions 4.0 International - CC BY-NC-SA 4.0

https://creativecommons.org/licenses/by-nc-sa/4.0/ 


\title{
Les clercs, les fidèles et les saints en Bourgogne médiévale
}

\author{
Textes réunis par Vincent Tabbagh
}

1 Éditions Universitaires de Dijon, 4, boulevard Gabriel - 21000 Dijon - ISBN 2-915552-21-5 ; ISSN 1628-5409, $20 €$.

2 Aux Bourguignons d'autrefois, les saints ont donné leur prénom, le patronage de leur église et parfois de leur village, l'occasion de leurs fêtes et leurs réjouissances. Auprès du capital sacré des reliques et des statues, les fidèles sont venus chercher guérison et protection ; ils ont vénéré les tombeaux après parfois un long voyage ; ils ont embrassé les saints restes, en déposant quelques pièces dans un tronc tout proche.

3 Mais qui étaient ces saints? Leurs ancêtres lointains, martyrs et premiers évêques, Reine, Bénigne et Léger, ou des membres de leur propre paroisse, de leur famille même, dont la ferveur avait soulevé leur admiration? De hautes figures de moines, comme Bernard, ou de simples gens sur lesquels chacun pouvait prendre modèle? La dévotion envers les saints est une affaire personnelle, la liberté de chacun trouve à s'y exprimer, mais c'est aussi l'expression de croyances collectives. À travers le choix des lieux d'inhumation, la vénération des tombeaux et des reliques, la multiplication des statues, l'achat des indulgences, ce livre met en évidence l'approche subtile et différenciée de ces saints mystérieux que le clerc comme le laïc cherche à rejoindre sans pouvoir revivre leur exemple.

4 Ont participé à cet ouvrage :

- Eliana MAGNANI SOARES, Le pauvre, le Christ et le moine : la correspondance de rôles et les cérémonies du mandatum à travers les coutumiers clunisiens du $\mathrm{XI}^{\mathrm{e}}$ siècle.

- Jean-Vincent JOURD'HEUIL, Sanctuaires, inhumations et sépultures des évêques de Langres des origines au XVI siècle.

- Jacques MADIGNIER, Être inhumé au cloître canonial d'Autun aux XII ${ }^{\mathrm{e}}, \mathrm{XIII}^{\mathrm{e}}$ et XIV $\mathrm{X}^{\mathrm{e}}$ siècles.

- Lucie MILANI, Une approche de la piété quotidienne : la statuaire de la Vierge à l'Enfant 1300-1500.

- Fabrice REY, Les réverbérations politiques de la dévotion princière : Marguerite de Flandre et Marguerite de Bavière aux pieds de la Vierge (1369-1424). 
-Vincent TABBAGH, Construction sacrée, réforme spirituelle et vénération des saints au milieu du XV $\mathrm{X}^{\mathrm{e}}$ siècle : l'exemple de la collégiale de Vergy.

- Laurent DURNECKER, Le culte des saints à Moutiers-Saint-Jean du Moyen Âge à la Réforme.

- Delphine LANNAUD, Les indulgences épiscopales bourguignonnes à la fin du Moye Âge : les conséquences financières d'un outil au service de l'activité pastorale. 